\title{
Metode Pengenalan Tempat Secara Visual Berbasis Fitur CNN untuk Navigasi Robot di Dalam Gedung
}

\author{
Visual Place Recognition Method Based-on CNN Features for Indoor Robot \\ Navigation
}

\author{
Hadha Afrisal $\left.{ }^{*}\right)$
}

Departemen Teknik Elektro, Fakultas Teknik, Universitas Diponegoro

Jl. Prof. Soedarto, SH, Kampus Undip Tembalang, Semarang, Indonesia 50275

\begin{abstract}
Cara sitasi: H. Afrisal, "Metode Pengenalan Tempat Secara Visual Berbasis Fitur CNN untuk Navigasi Robot di Dalam Gedung," Jurnal Teknologi dan Sistem Komputer, vol. 7 no. 2, 2019. doi: 10.14710/jtsiskom.7.2.2019.4755, [Online].
\end{abstract}

\begin{abstract}
Place recognition algorithm based-on visual sensor is crucial to be developed especially for an application of indoor robot navigation in which a Ground Positioning System (GPS) is not reliable to be utilized. This research compares the approach of place recognition of using learned-features from a model of Convolutional Neural Network (CNN) against conventional methods, such as Bag of Words (BoW) with SIFT features and Histogram of Oriented Uniform Patterns (HOUP) with its Local Binary Patterns (LBP). This research finding shows that the performance of our approach of using learnedfeatures with transfer learning method from pretrained CNN AlexNet is better than the conventional methods based-on handcrafted-features such as BoW and HOUP.
\end{abstract}

Keywords - place recognition; convolutional neural network; visual navigation; mobile robot

\begin{abstract}
Abstrak - Algoritma pengenalan tempat berbasis sensor visual penting untuk dikembangkan, terutama untuk aplikasi navigasi robot di dalam gedung dimana Ground Positioning System (GPS) tidak reliabel untuk digunakan. Penelitian ini membandingkan antara pendekatan berbasiskan learned-features yang diperoleh dari model Convolutional Neural Network (CNN), terhadap metode konvensional berbasis handcrafted-features, seperti Bag of Words (BoW) dengan fitur SIFT dan Histogram of Oriented Uniform Patterns (HOUP) dengan Local Binary Patterns (LBP). Hasil pengujian menunjukkan bahwa performa pendekatan learned-features dengan metode transfer learning pada pre-trained CNN AlexNet memiliki performa yang lebih baik dibandingkan metode konvensional berbasis handcrafted features seperti BoW dan HOUP.
\end{abstract}

Kata kunci - pengenalan tempat; convolutional neural network; navigasi visual; robot bergerak

\footnotetext{
*) Penulis korespondensi (Hadha Afrisal)

Email: hadha.afrisal@elektro.undip.ac.id
}

\section{Pendahuluan}

Dalam beberapa dekade terakhir, aplikasi robotbergerak (mobile-robot) semakin banyak dibutuhkan di dunia industri, salah satunya sebagai instrumen transportasi serta distribusi logistik secara otomatis. Dalam beberapa setting industri, robot-bergerak diharuskan untuk bernavigasi dari satu tempat ke tempat lain secara otomatis guna mengambil barang dan mendistribusikannya ke beberapa ruangan dalam satu gedung. Robot tersebut ditugaskan untuk mengenal dan mengingat ruang-ruang yang pernah disinggahi, sehingga proses distribusi logistik yang melibatkan proses memuat dan menurunkan barang dapat terlaksana secara tepat. Dalam skenario tersebut, robot-bergerak wajib dibekali dengan kemampuan pengenalan dan pengingat lokasi. Pada perkembangannya, metode pengenalan tempat untuk navigasi robot-bergerak menjadi dasar dalam pengembangan metode Simultaneous Localisation and Mapping (SLAM). Metode SLAM sampai saat ini pengembangannya masih dalam tahap awal dan membutuhkan inovasi algoritma untuk meningkatkan performa dan akurasinya [1].

Metode pengenalan tempat berbasiskan citra digital menggunakan sensor kamera pada robot-bergerak merupakan salah satu solusi untuk pengembangan SLAM, terutama pada aplikasi navigasi indoor. Pada umumnya, navigasi robot (yang melibatkan positioning dan localization) berpedoman pada sensor GPS saja. Namun, pada lokasi indoor pembacaan nilai GPS cenderung tidak dapat diandalkan karena memiliki kepresisian dan akurasi yang rendah [2]. Penggunaan sensor visual, seperti kamera, menjadi alternatif yang tepat untuk skenario ini. Kamera sebagai sensor utama pada robot-bergerak juga dinilai lebih menguntungkan karena instalasi dan perawatannya yang cukup mudah dan harganya yang terjangkau jika dibandingkan dengan sensor-sensor lain, seperti laser range finder, ultrasound, infra-red, dan sejenisnya.

Pada teknik visual SLAM, beberapa pendekatan berbasiskan handcrafted features atau fitur buatan telah banyak dikembangkan, antara lain SIFT [3] dan SURF 
[4] yang berbasiskan fitur lokal berbentuk vektor, BRISK [5] dan ORB [6] yang berbasiskan fitur lokal berbentuk biner, serta fitur dan deskriptor lain yang dikenali oleh penglihatan manusia, seperti garis [7] maupun sudut dan tepi [8].

Salah satu metode pengenalan tempat yang cukup banyak digunakan saat ini adalah Bag-of-Words (BoW) atau Bag-of-Features (BoF). Metode tersebut secara umum terdiri dari tahapan: (1) ekstraksi fitur lokal pada citra, (2) proses encoding fitur lokal sebagai deskriptor, dan (3) klasifikasi deskriptor citra [9]. Salah satu teknik pengenalan tempat berbasis BoW telah berhasil didemonstrasikan dengan algoritma Dorian [10], yakni dengan menggunakan teknik encoding biner untuk mendeskripsikan fitur-fitur yang telah diekstraksi dari citra digital. Metode tersebut cukup efektif dan efisien untuk pengenalan tempat. Namun, metode tersebut memiliki akurasi yang cukup rendah jika digunakan pada citra-citra yang memiliki bentuk rotasi dan skala perspektif yang bervariasi. Selain itu, tantangan lain dalam pengembangan teknik BoW yang paling banyak ditemukan adalah algoritma tersebut tidak dapat digunakan pada citra-citra yang memilki struktur atau pola bentuk yang repetitif dalam citra yang sama. Padahal pada umumnya penggunaan robot-bergerak di lokasi indoor banyak menemui pola-pola visual repetitif tersebut, seperti misalnya pada ubin-ubin, pola pada plafon, pintu, jendela, dan lain sebagainya [11]. Selain itu, metode-metode konvensional berbasiskan BoW pada umumnya memiliki akurasi yang rendah jika digunakan pada kondisi cahaya yang berubah-ubah serta dengan sudut pandang kamera yang beragam [12].

Perkembangan teknik machine learning (pembelajaran-mesin) dan deep learning (pembelajaranmendalam) memberikan alternatif terobosan baru dalam pengembangan metode pengenalan tempat menggunakan citra digital yakni dengan menggunakan Convolutional Neural Network (CNN) [13]. CNN dengan learned-features (fitur hasil-pembelajaran) yang dihasilkan dapat digunakan untuk menyelesaikan permasalahan-permasalahan yang ada pada proses pengenalan objek dan pemulihan citra, misalnya pada metode pengenalan dan kategorisasi tempat [14].

Implementasi metode tersebut untuk aplikasi robotbergerak masih menemui banyak tantangan dan keterbatasan, terutama terkait dengan dinamika serta tingginya tingkat ketidakpastian di dunia nyata. Jumlah citra yang digunakan dalam proses training haruslah mencukupi dan representatif (tidak overfitting maupun underfitting). Selain itu, kemungkinan jumlah citra dalam proses training akan menjadi jauh lebih besar karena proses tersebut berlangsung secara terus menerus dan dalam waktu cukup lama [15]. Sebagai solusi atas tantangan serta keterbatasan yang ada pada metodemetode terdahulu, penelitian ini bertujuan untuk mengembangkan metode alternatif untuk pengenalan tempat dan kategorisasi citra lokasi indoor dengan menggunakan metode transfer learning CNN yang berbasis learned-features.

\section{Metode Penelitian}

Penelitian ini bertujuan untuk menguji metode transfer learning CNN yang berbasiskan learnedfeatures dan membandingkan performanya terhadap metode konvensional yang berbasiskan handcraftedfeatures. Eksperimen yang dilakukan menggunakan pendekatan baru, yakni memanfaatkan learned-features dari teknik transfer learning pada arsitektur CNN AlexNet [16]. Metode konvensional Bag of Words (BoW) [10] dan Histogram of Oriented Uniform Pattern (HOUP) [17] digunakan sebagai pembanding terhadap metode yang dikembangkan tersebut. Pengujian dilakukan secara offline dengan menggunakan software Matlab pada komputer dengan CPU Intel Core i5 2,8 GHz dan kapasitas RAM 4 GB.

\section{A. Dataset Citra Indoor}

Untuk membandingkan performa metode yang dikembangkan terhadap metode konvensional yang sudah ada, secara fair eksperimen ini akan memanfaatkan 2 jenis dataset, yaitu Indoor Scene Recognition (ISR) CVPR MIT dataset [18] dan York University dataset [17]. Dataset ISR-CVPR MIT dipilih karena memiliki jumlah kategori citra yang relatif banyak dan dengan sudut pandang serta variasi fitur yang cukup untuk menguji akurasi algoritma pada kategori kelas yang cukup besar. Dataset York University ini dipilih sebagai data uji karena citra direkam menggunakan 2 jenis robot-bergerak yang berbeda dan dalam kondisi iluminasi yang berbeda, sehingga cocok untuk menguji kepresisian dan repeatability dari algoritma yang dikembangkan dalam situasi dan setting yang variatif.

Dataset ISR-CVPR MIT terdiri dari 67 kategori tempat indoor dengan total citra sejumlah 15.620 yang mana terdapat sekurang-kurangnya 100 citra pada tiap kategorinya. Citra dataset berformat JPG dengan klasifikasi jenis tempat yang beragam dari mulai store, home, public spaces, leisure, dan working places. Dataset York University terdiri dari 11 dan 17 kategori ruangan dengan jumlah total citra 29.917 berformat PNG dengan resolusi 640 x 480 piksel. Citra-citra ruangan tersebut diambil dengan menggunakan sensor kamera Point Grey Bumblebee dari 2 robot yang berbeda, yakni robot Pioneer (tinggi $88 \mathrm{~cm}$ ) dan Virtual Me (tinggi $117 \mathrm{~cm}$ ). Dataset diambil pada 2 kondisi pencahayaan yang berbeda, yakni pada siang dan malam hari.

\section{B. Deskriptor Fitur Citra}

Deskriptor citra merepresentasikan informasi unik yang dikandung oleh sebuah citra dalam bentuk keypoints[19]. Deskriptor citra diklasifikasikan ke dalam 2 jenis, yaitu handcrafted-features descriptor dan learned-features descriptor [13]. 


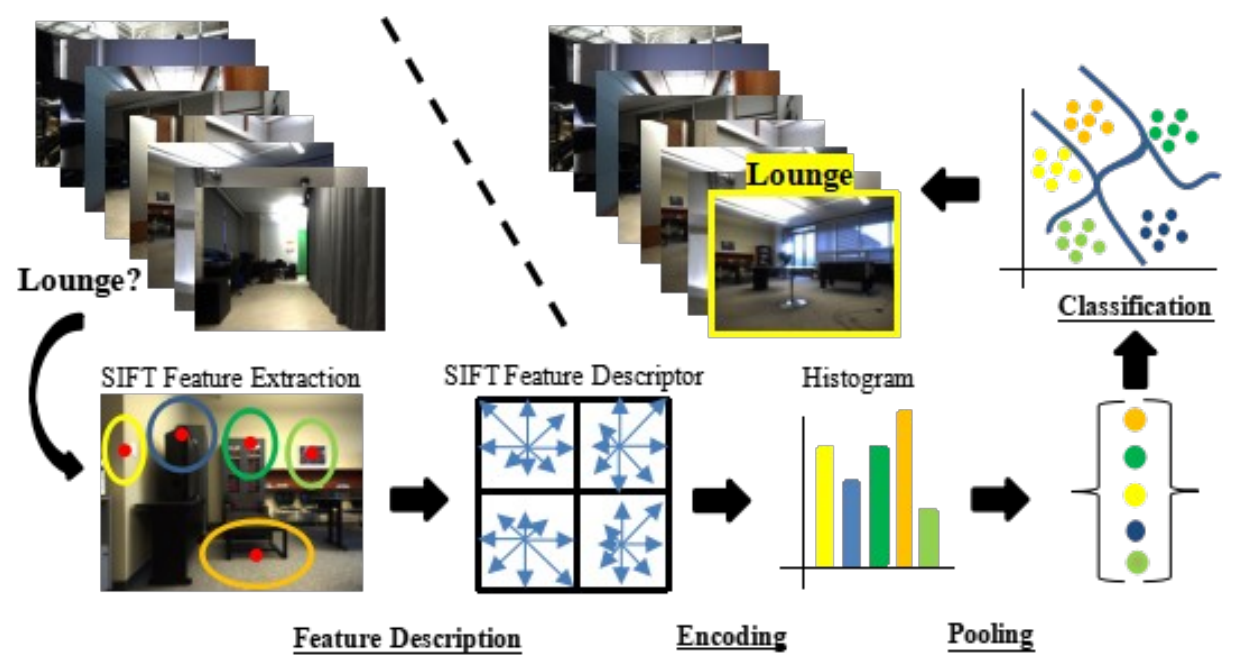

Gambar 1. Pipeline pembentukan deskriptor BoW dengan fitur SIFT

\section{Handcrafted-Features Descriptor: BoW dan HOUP}

Handcrafted-features atau fitur buatan-tangan, diperoleh dari teknik ekstraksi fitur lokal menggunakan ekstraktor yang telah ditentukan polanya, misalnya Scale Invariant Feature Transform (SIFT) [3] dan Speeded-up Robust Features (SURF) [4]. Pada penelitian ini, 2 buah handcrafted-features descriptor yang digunakan dan dibandingkan performanya adalah Bag of Words (BoW) dan Histogram of Oriented Uniform Patterns (HOUP).

Metode Bag of Words (BoW) digunakan dalam penelitian sebagai deskriptor citra untuk proses klasifikasi dan pengenalan objek dalam bidang computer vision dan disebut sebagai Bag of Visual Words, sebagai representasi dari kelompok fitur pada citra yang disandikan melalui deskriptor. Pada penelitian ini, fitur yang digunakan dalam BoW adalah SIFT. Pipeline deskriptor BoW dengan fitur SIFT ditunjukkan pada Gambar 1, yakni terdiri dari 4 tahapan utama, yaitu: (1) ektraksi fitur menggunakan SIFT, (2) proses encoding menggunakan histogram, (3) proses max pooling untuk masing-masing wilayah spasial pada fitur, dan (4) proses klasifikasi. Pada metode BoW yang dilakukan di penelitian ini, proses klasifikasi menggunakan Support Vector Machine (SVM).

Fitur yang diperoleh dengan SIFT sebagai keypoints, berbentuk lingkaran yang menandai sebuah wilayah citra, lengkap dengan orientasi gradien (Gambar 1). Deskriptor SIFT pada sebuah keypoint merupakan bentuk histogram spasial 3-D dari gradien citra. Gradien pada masing-masing piksel dianggap sebagai sampel dari dasar fitur vektor 3 dimensi, yang didefinisikan dari lokasi piksel dan juga orientasi gradien. Sampel-sampel tersebut ditimbang dan dinormalisasi terhadap histogram 3 dimensi secara total. Standar SIFT menggunakan fungsi pembobotan model Gaussian untuk mengeliminasi nilai-nilai gradien yang terlalu jauh dari titik pusat keypoint. Pada eksperimen yang dilakukan, metode SIFT yang digunakan mengacu pada standar SIFT pada VLFeat [20] yang berbeda dengan

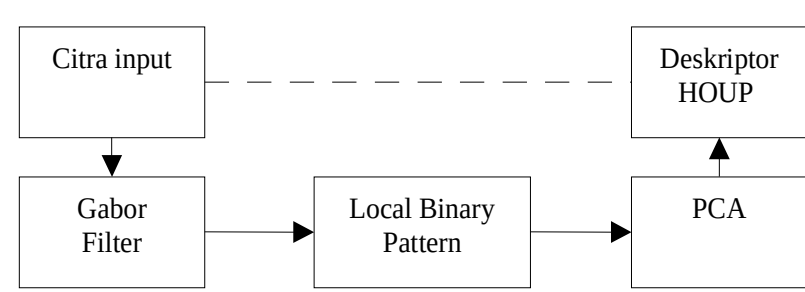

Gambar 2. Pipeline pembentukan deskriptor HOUP

metode SIFT original yang dikembangkan [3], yakni menggunakan y-axis ke arah bawah dan konvensi orientasi searah putaran jarum jam.

Histogram of Oriented Uniform Patterns (HOUP) sebagai bentuk deskriptor citra digunakan untuk pengenalan tempat dan kategorisasi citra [21]. Metode ini menggunakan Gabor filter untuk memfiltrasi subblok pada citra dengan orientasi yang berbeda-beda (Gambar 2). Output dari Gabor filter tersebut digunakan untuk menghitung Local Binary Patterns (LBP). Principal Component Analysis (PCA) digunakan untuk mengurangi dimensionalitas dari jumlah fitur yang diperoleh,

\section{Learned-Features Descriptor: TL-AlexNet}

Learned-descriptor sebagai bentuk deskripsi citra menggunakan fitur-fitur yang dihasilkan dari pembelajaran-mesin (machine learning) [13]. Pada penelitian ini, learned-features diperoleh dari metode transfer learning dari arsitektur Convolutional Neural Network (CNN) AlexNet [16]. Pendekatan transfer learning untuk pembelajaran mesin menggunakan sebuah model yang sudah dilatih pada dataset tertentu untuk kemudian digunakan kembali (re-purposed) pada dataset dengan setting dan keperluan yang lain.

Pre-trained AlexNet digunakan untuk tujuan baru yaitu sebagai metode pengenalan tempat dengan pendekatan transfer learning ini. Model tersebut sudah terbukti memiliki performa yang sangat baik pada ImageNet Large-Scale Visual Recognition Challenge 


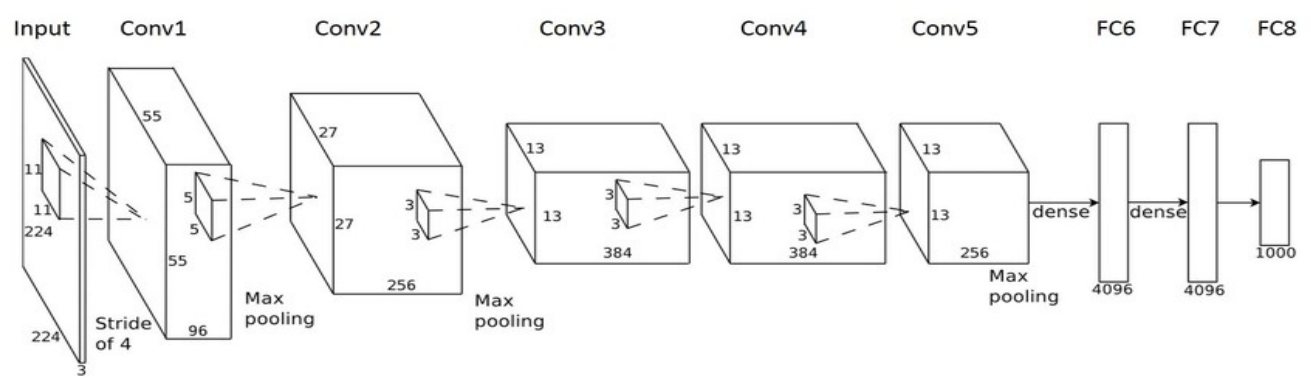

Gambar 3. Model Convolutional Neural Network (CNN) AlexNet [16]
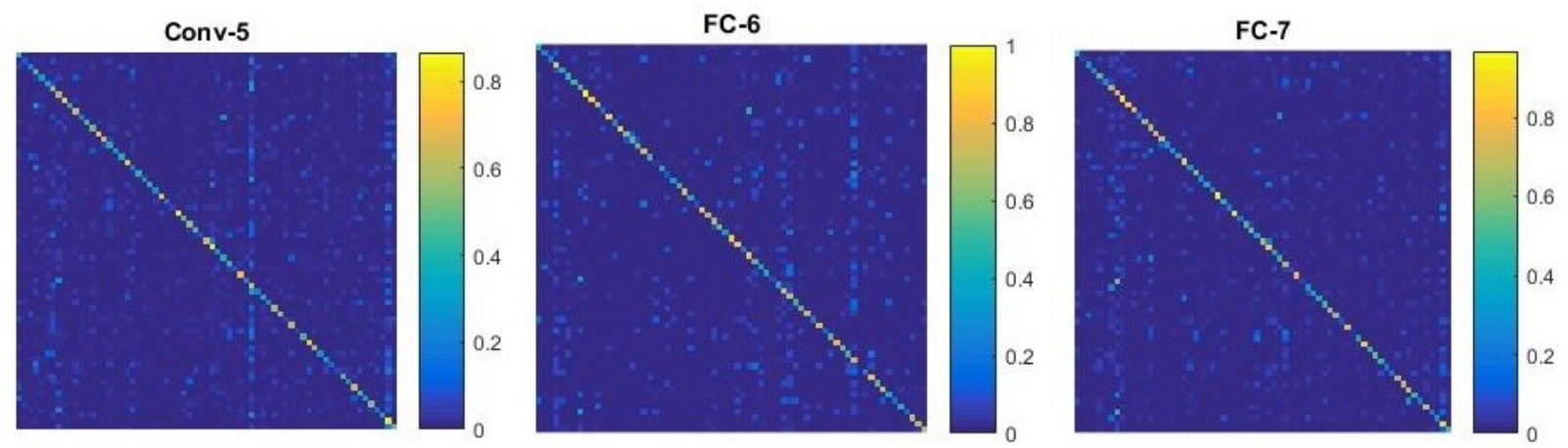

Gambar 4. Visualisasi confusion matrix dari pengujian terhadap dataset ISR-CVPR (67 kategori) dengan metode transfer learning AlexNet pada layer Conv-5, FC-6, dan FC-7, dimana sumbu Y merepresentasikan kategori citra sebenarnya (actual category) dan sumbu X merepresentasikan kategori citra hasil prediksi (predicted category)

(ILSVRC-2012), yakni meraih peringkat top-5 dengan tingkat galat cukup kecil yakni 15,3\%[22]. Hal ini sesuai dengan intuisi otak manusia, yaitu bahwa sebuah tempat biasanya terdapat beberapa objek yang familiar, misalnya peralatan-peralatan dapur di dapur, komputer dan meja kerja di kantor, atau ubin dan plafon atau pintu-pintu dalam jumlah banyak di lorong. Fitur-fitur yang telah ada pada pre-trained model AlexNet digunakan kembali untuk mengenali tempat. Model pretrained AlexNet digunakan dengan MatConvNet [23] pada Matlab. Citra-citra pada dataset sebelumnya dilakukan preproses dengan melakukan skala ulang menjadi ukuran 227 x 227 piksel agar sesuai dengan spesifikasi pada model CNN AlexNet.

Eksperimen dilakukan dengan cara membandingkan performa metode berbasis learned-features terhadap metode konvensional yang berbasiskan handcraftedfeatures, yaitu meliputi tahapan berikut (Gambar 3):

1. Menguji performa metode Transfer Learning (TL) menggunakan pre-trained CNN dengan arsitektur AlexNet, dimana fitur-fitur yang diekstraksi dan diolah adalah dari layer ke-5 (convolutional 5), ke6 (fully-connected layer 6), dan ke-7 (fullyconnected layer 7). Performa transfer learning dengan accuracy, precision, recall, dan F1 score terbaik kemudian digunakan sebagai pembanding terhadap metode konvensional berbasis handcrafted-features.

2. Metode berbasiskan learned-features dengan performa terbaik kemudian dibandingkan dengan metode konvensional yang paling banyak digunakan serta dengan performa yang relatif paling baik dalam metode pengenalan objek, yakni (a) BoW berfitur SIFT dengan pengklasifikasi SVM, dan (b) HOUP dengan LBP yang sudah direduksi dimensionalitasnya menggunakan metode PCA.

Perhitungan nilai accuracy, precision, recall, dan F1 score menggunakan Persamaan 1 sampai Persamaan 4. TP menyatakan True Positive, TN True Negative, FP False Positive, dan FN False Negative.

$$
\begin{gathered}
\text { Accuracy }=\frac{T P+T N}{T P+F P+T N+F N} \\
\text { Precision }=\frac{T P}{T P+F P} \\
\text { Recall }=\frac{T P}{T P+F N} \\
F 1_{\text {score }}=2 \times \frac{\text { Recall } \times \text { Precision }}{\text { Recall }+ \text { Precision }}
\end{gathered}
$$

\section{Hasil dan PeMbahasan}

Pengujian awal berusaha membandingkan performa metode transfer learning pada layer 5, 6, dan 7, terhadap 2 buah dataset, yaitu: ISR-CVPR dan York Univ, dimana masing-masing dataset memiliki jumlah kategori dan jenis citra yang berbeda. Confusion matrix yang dihasilkan dari proses klasifikasi 67 kategori citra tempat indoor menggunakan dataset ISR-CVPR (Gambar 4). Matriks tersebut menunjukkan bahwa 


\begin{tabular}{|c|c|c|}
\hline & $\square$ Conv-5 $\square$ FC-6 $\square$ FC & \\
\hline winecellar [67] & 0.494 & 0.519 \\
\hline warehouse [66] & 0.829 & 0.888 \\
\hline waitingroom [65] & 0.733 & 0.289 \\
\hline videostore [64] & 0.182 & 0.212 \\
\hline tv_studio [63] & 0.520 & 0.700 \\
\hline trainstation [62] & 0.326 & 0.239 \\
\hline [61] & 0.429 & 0.481 \\
\hline & 0.654 & 0.698 \\
\hline studiomusic [59] & 0.281 & 0.719 \\
\hline staircase [58] & 0.478 & 0.652 \\
\hline shoeshop [57] & 0.250 & 0.229 \\
\hline resto_kit & 0.156 & 0.188 \\
\hline [55] & 0.338 & 0.494 \\
\hline 54] & 0.290 & 0.548 \\
\hline pool_i & 0.596 & 0.481 \\
\hline 52] & 0.774 & 0.852 \\
\hline erating_r & 0.538 & 0.400 \\
\hline 50] & 0.061 & 0.030 \\
\hline nursery [49] & 0.786 & 0.767 \\
\hline 18] & 0.235 & 0.120 \\
\hline movieth & 0.566 & 0.642 \\
\hline meeting_roo & 0.571 & 0.643 \\
\hline 45] & 0.245 & 0.509 \\
\hline locker_roc & 0.760 & 0.440 \\
\hline [43] & 0.800 & 0.400 \\
\hline livingro & 0.675 & 0.377 \\
\hline & 0.250 & 0.0910 .063 \\
\hline laundro & 0.723 & 0.795 \\
\hline laborato & 0.108 & 0.081 \\
\hline & 0.575 & 0.677 \\
\hline kinderg & 0.846 & 0.474 \\
\hline jewellery & 0.298 & 0.447 \\
\hline inside_ & 0.848 & 0.847 \\
\hline inside & 0.645 & 0.645 \\
\hline hospital & 0.400 & 0.400 \\
\hline 32] & $0.486 \quad 0.583$ & 0.583 \\
\hline 31] & 0.551 & 0.507 \\
\hline grocerystore [30] & 0.469 & 0.234 \\
\hline green & 0.900 & 0.933 \\
\hline 28] & 0.0650 .100 & 226 \\
\hline gamerc & 0.184 & 0.447 \\
\hline 26] & 0.742 & 0.968 \\
\hline fastfood & 0.500 & 0.257 \\
\hline & 0.433 & 0.433 \\
\hline $\operatorname{dinin}$ & 0.111 & 0.293 \\
\hline denta & 0.410 & 0.590 \\
\hline deli [21] & 0.208 & 351 \\
\hline corridor [20] & 0.788 & 0.856 \\
\hline concert & 0.387 & 0.419 \\
\hline computerroom [18] & 0.294 & 0.353 \\
\hline clothings & 0.545 & 0.313 \\
\hline 16] & 0.615 & 0.750 \\
\hline [15] & 0.917 & 0.750 \\
\hline classr & 0.273 & 0.676 \\
\hline church_ & 0.889 & 0.630 \\
\hline children_r & 0.182 & 0.235 \\
\hline [11] & 0.745 & 0.740 \\
\hline [10] & 0.394 & 0.818 \\
\hline [9] & 1.000 & 0.922 \\
\hline bookstore [8] & 0.526 & 0.772 \\
\hline bedroom [7] & 0.515 & 0.668 \\
\hline bathroom [6] & 0.500 & 0.288 \\
\hline bar [5] & 0.304 & 0.558 \\
\hline bakery [4] & 0.850 & $0.29 \varepsilon$ \\
\hline auditorium [3] & 0.245 & 0.358 \\
\hline artstudio [2] & 0.095 & $0.04 \varepsilon$ \\
\hline airport_inside [1] & 0.451 & 0.473 \\
\hline
\end{tabular}

$0 \%$
$50 \%$

$100 \%$

Gambar 5. Perbandingan nilai akurasi dalam rentang 0 $-1(0-100 \%)$ pada masing-masing kategori citra dataset ISR-CVPR menggunakan metode pengujian TL-AlexNet pada FC-7, FC-6, dan Conv-5

Tabel 1. Nilai accuracy, precision, recall, dan F1 score untuk masing-masing proses klasifikasi dataset ISRCVPR (67 kategori) menggunakan metode TL dengan mengambil fitur CNN AlexNet pada layer 5 (Conv-5), 6 (FC-6), dan 7 (FC-7)

\begin{tabular}{ccccc}
\hline $\begin{array}{c}\text { CNN } \\
\text { Layer }\end{array}$ & Accuracy & Precision & Recall & $\begin{array}{c}\text { F1 } \\
\text { Score }\end{array}$ \\
\hline Conv-5 & 0,427 & 0,427 & 0,507 & 0,464 \\
FC-6 & 0,542 & 0,542 & 0,612 & 0,575 \\
FC-7 & 0,503 & 0,503 & 0,578 & 0,538 \\
\hline
\end{tabular}

model transfer learning pada layer 5, 6, dan 7 AlexNet untuk dataset ISR-CVPR dengan jumlah 67 kategori citra masih memiliki akurasi cukup baik karena secara visual nilai TP pada diagonal matriks masih bernilai cukup tinggi.

Secara lebih detail, nilai sebaran akurasi pada masing-masing kategori citra ditampilkan pada Gambar 5. Dari pengujian yang dilakukan, terlihat bahwa secara umum nilai akurasi pada masing-masing kategori untuk metode TL-AlexNet FC-6 lebih dominan mengungguli Conv-5 dan FC-7. Nilai akurasi Conv-5 dan FC-7 hanya unggul pada beberapa kategori saja, sedangkan FC-6 unggul pada lebih dari 50\% jumlah kategori yang ada.

Perbandingan performa secara keseluruhan dari masing-masing metode TL-AlexNet, nilai accuracy, precision, recall, dan F1 score disajikan pada Tabel 1 sesuai dengan perhitungan menggunakan Persamaan 14. Performa keseluruhan dari metode TL-AlexNet pada FC-6 mengungguli dua layer lain (Conv-5 dan FC-7), yakni dengan accuracy $54,2 \%$, precision $54,2 \%$, recall $61,2 \%$, dan F1 score 57,5\%. Dengan keunggulan tersebut, maka dapat disimpulkan bahwa metode TLAlexNet paling optimal berada pada layer ke-6, yaitu Fully-Connected Layer 6, untuk dataset ISR-CVPR dengan 67 kategori citra.

Selanjutnya, ketiga buah metode TL-AlexNet (Conv-5, FC-6, dan FC-7) diujikan terhadap dataset York Univ dengan 17 kategori citra lokasi indoor. Confusion matrix yang dihasilkan dari metode TLAlexNet pada Conv-5, FC-6, dan FC-7 ditampilkan pada Gambar 6. Secara visual, ketiga metode TLAlexNet tersebut juga menunjukkan performa yang cukup baik dalam mengkategorikan citra lokasi indoor. Hal ini terlihat dari rendahnya nilai citra yang terklasifikasi secara salah serta cukup tingginya nilai akurasi, yaitu pada bagian diagonal confusion matrix. Satu-satunya kategori citra yang memiliki nilai akurasi rendah adalah pada kategori Plant-Room.

Perbandingan nilai akurasi pada masing-masing metode TL-AlexNet untuk proses kategorisasi citra lokasi dataset York Univ disajikan pada Gambar 7. Hasil eksperimen tersebut memperlihatkan bahwa secara umum metode TL-AlexNet pada FC-6 mengungguli metode dengan layer Conv-5 dan FC-7. Performa secara keseluruhan metode TL-AlexNet pada Conv-5, FC-6, dan FC-7 ditunjukkan pada Tabel 2. Metode TL-AlexNet pada FC-6 unggul dalam hal nilai 

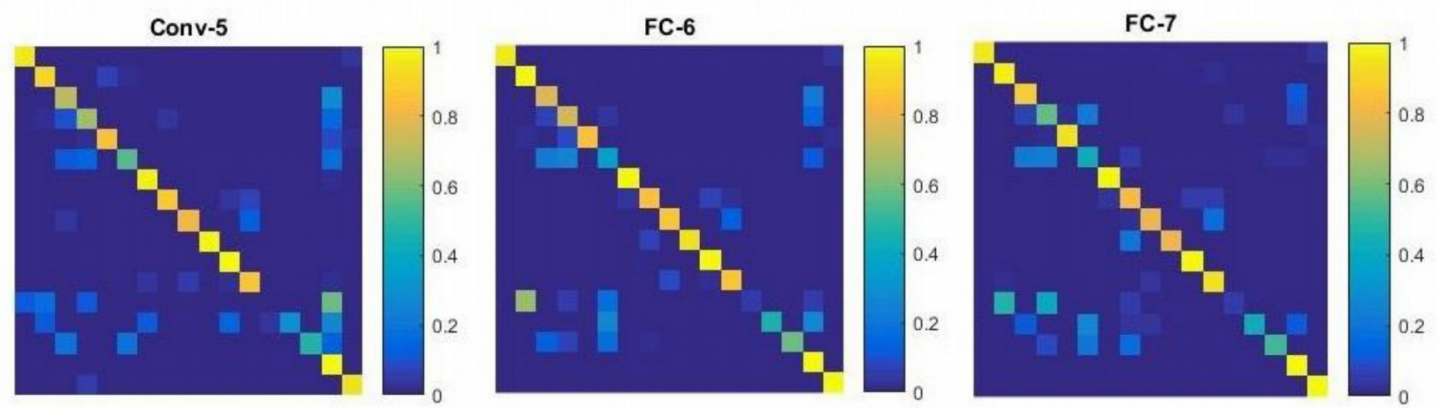

Gambar 6. Visualisasi confusion matrix dari pengujian terhadap dataset York Univ (17 kategori) dengan metode transfer learning AlexNet pada layer Conv-5, FC-6, dan FC-7, dimana sumbu Y merepresentasikan kategori citra sebenarnya (actual category) dan sumbu X merepresentasikan kategori citra hasil prediksi (predicted category)

accuracy $(78,5 \%)$, precision $(78,4 \%)$, recall $(83,3 \%)$, dan F1 Score (80,8\%).

Secara lebih detail, nilai sebaran akurasi pada masing-masing kategori citra ditampilkan pada Gambar 5. Dari pengujian yang dilakukan, terlihat bahwa secara umum nilai akurasi pada masing-masing kategori untuk metode TL-AlexNet FC-6 lebih dominan mengungguli Conv-5 dan FC-7. Nilai akurasi Conv-5 dan FC-7 hanya unggul pada beberapa kategori saja, sedangkan FC-6 unggul pada lebih dari 50\% jumlah kategori yang ada.

Guna membandingkan performa secara keseluruhan masing-masing metode TL-AlexNet, nilai accuracy, precision, recall, dan F1 score disajikan pada Tabel 1, sesuai dengan perhitungan pada Persamaan 1-4. Dari Tabel 1 tersebut, terlihat bahwa performa keseluruhan dari metode TL-AlexNet pada FC-6 mengungguli dua layer lain (Conv-5 dan FC-7), yaitu dengan accuracy 54,2\%, precision 54,2\%, recall 61,2\%, dan F1 score $57,5 \%$. Dengan keunggulan tersebut, maka dapat disimpulkan bahwa metode TL-AlexNet paling optimal berada pada layer ke-6, yaitu Fully-Connected Layer 6, untuk dataset ISR-CVPR dengan 67 kategori citra.

Selanjutnya, ketiga buah metode TL-AlexNet (Conv-5, FC-6, dan FC-7) akan diujikan terhadap dataset York Univ dengan 17 kategori citra lokasi indoor. Confusion matrix yang dihasilkan dari metode TL-AlexNet pada Conv-5, FC-6, dan FC-7 ditampilkan pada Gambar 6. Secara visual, ketiga metode TLAlexNet tersebut juga menunjukkan performa yang cukup baik dalam mengkategorikan citra lokasi indoor. Hal ini terlihat dari rendahnya nilai citra yang terklasifikasi secara salah serta cukup tingginya nilai akurasi pada bagian diagonal confusion matrix. Satusatunya kategori citra yang memiliki nilai akurasi rendah adalah pada kategori Plant-Room.

Perbandingan nilai akurasi pada masing-masing metode TL-AlexNet untuk proses kategorisasi citra lokasi dataset York Univ disajikan pada Gambar 7. Hasil eksperimen tersebut memperlihatkan bahwa secara umum metode TL-AlexNet pada FC-6 mengungguli metode dengan layer Conv-5 dan FC-7. Selanjutnya, performa secara keseluruhan metode TLAlexNet pada Conv-5, FC-6, dan FC-7 ditampilkan pada Tabel 2. Pada Tabel 2 tersebut terlihat bahwa
Conv-5 FC-6 $\square$ FC-7

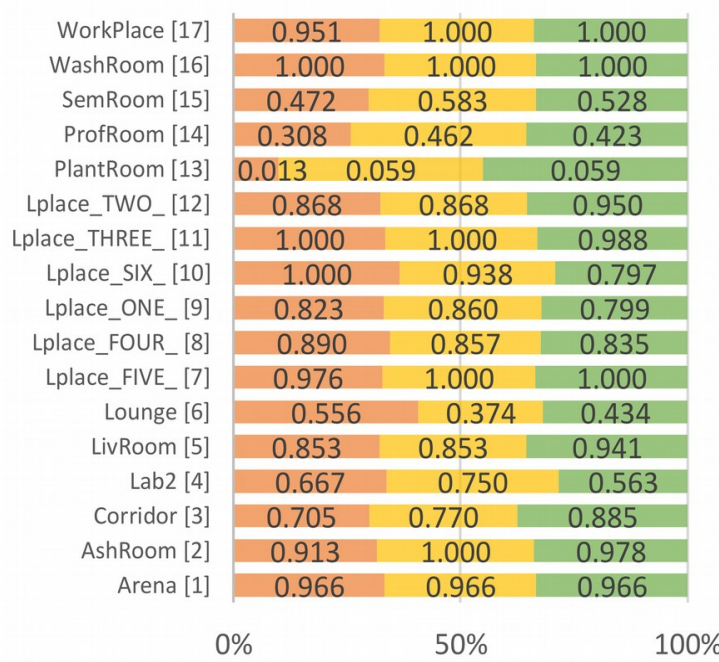

Gambar 7. Perbandingan nilai akurasi dalam rentang 0 - $1(0-100 \%)$ pada masing-masing kelas citra dataset York University (17 places), menggunakan metode pengujian TL-AlexNet pada FC-7, FC-6, dan Conv-5

metode TL-AlexNet pada FC-6 unggul dalam hal nilai accuracy (78,5\%), precision (78,4\%), recall $(83,3 \%)$, dan F1 Score (80,8\%).

Dari pengujian tersebut, dapat diperoleh kesimpulan bahwa metode Transfer Learning menggunakan pretrained CNN AlexNet memiliki performa yang maksimal jika dilakukan pada layer ke-6, yaitu FullyConnected Layer 6 (FC-6). Untuk selanjutnya, metode TL-AlexNet FC-6 tersebut akan digunakan sebagai pembanding terhadap 2 jenis metode konvensional yang menggunakan handcrafted-features, yaitu BoW dengan fitur SIFT pengklasifikasi SVM dan HOUP fitur LBP.

Pada pengujian, factor perubahan iluminasi dan format citra yang berbeda juga akan menjadi parameter pengujian, sehingga pada pengujian akan digunakan dataset York Univ dengan 11 kategori. Hal ini disebabkan dataset dengan 11 kategori memiliki parameter yang lebih variatif, yaitu selain diambil pada siang dan malam hari, dataset tersebut juga diambil 


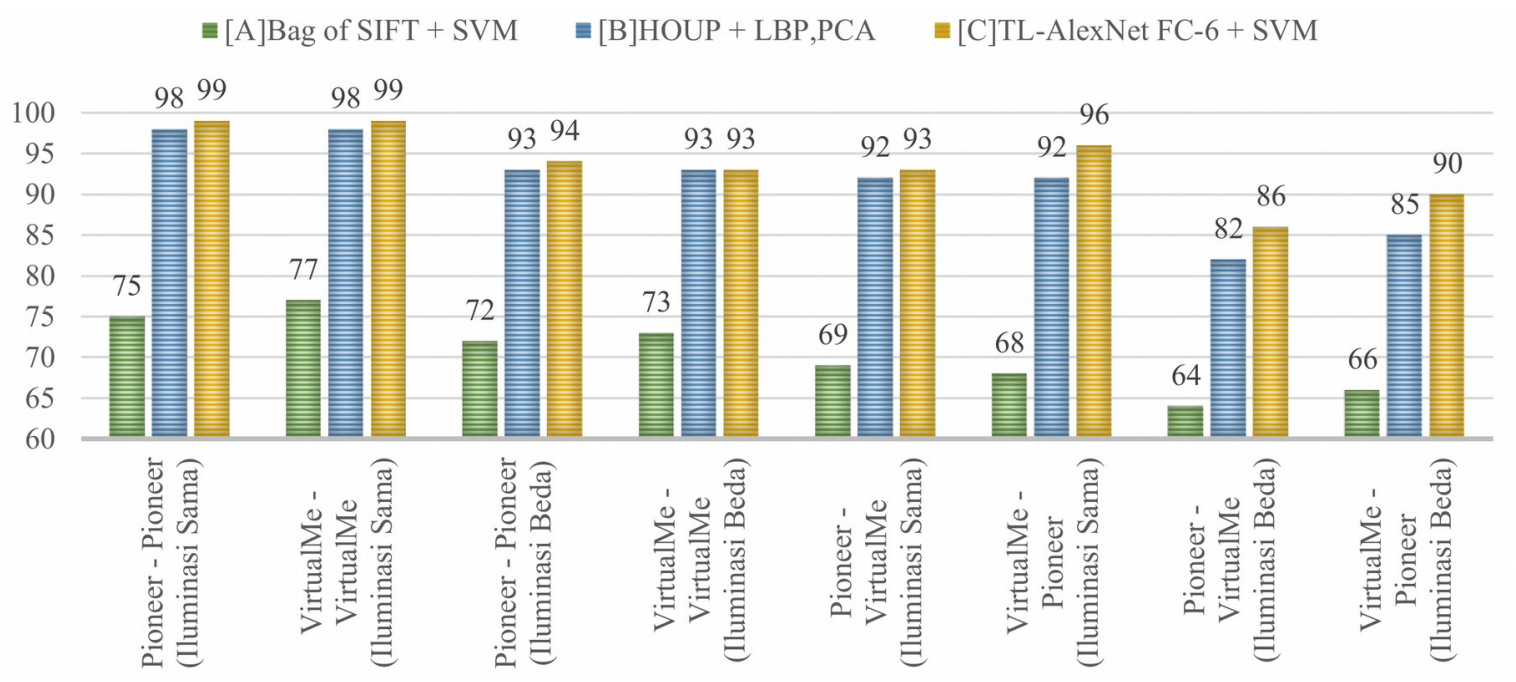

Gambar 8. Perbandingan nilai akurasi 3 jenis algoritma pengenalan tempat (dalam \%), yakni yang menggunakan handcrafted features: ${ }^{[\mathrm{A}]}$ Metode Bag of Words menggunakan fitur SIFT (Scale Invariant Feature Transform) dengan pengklasifikasi menggunakan Support Vector Machine (SVM) dan ${ }^{[\mathrm{B}]}$ Histogram of Oriented Uniform Pattern (HOUP) menggunakan Local Binary Patterns (LBP) dan Principal Component

Analysis (PCA) [ ], serta yang menggunakan learned features yakni: ${ }^{\left[{ }^{[}\right]}$Metode Transfer Learning menggunakan Convolutional Neural Network berarsitektur Alex-Net pada Fully Connected Layer ke-6, dengan kondisi uji iluminasi bervariasi.

menggunakan 2 jenis robot yang berbeda, yaitu robot Pioneer dan Virtual Me.

Hasil pengujian ditampilkan pada Gambar 8 dan Tabel 3. Pada Metode BoW dengan fitur SIFT memiliki performa paling rendah, sedangkan metode HOUP dan TL-AlexNet FC-6 bersaing ketat (Gambar 8). Pada citra training dan uji dengan iluminasi sama pada robot yang sama, HOUP cenderung memiliki performa yang hampir sama dengan TL-AlexNet FC-6, namun ketika kondisi iluminasi berbeda dan dengan robot berbeda untuk training dan tes, performa HOUP menurun secara signifikan. Sedangkan metode TL-AlexNet FC-6 relatif lebih stabil dengan nilai akurasi yang cukup tinggi. Hal ini dapat dilihat pada grafik komparasi paling kanan, yaitu ketika pengujian robot berbeda dan iluminasi berbeda, TL-AlexNet FC-6 masih mencapai 90\% akurasi atau 5\% di atas akurasi HOUP.

Nilai performa tertinggi dicapai ketika kondisi pencahayaan sama dan dengan robot yang berbeda, pada kondisi tersebut metode TL-AlexNet FC-6 mampu mencapai nilai accuracy 99\%, precision 98\%, recall 98\%, dan F1 score 98\%. Perubahan iluminasi berpengaruh terhadap menurunnya nilai performansi metode pengenalan tempat berbasis citra pada semua jenis metode. Namun, pada metode TL-AlexNet FC-6 penurunan nilai performansi tidak terlalu signifikan, bahkan dengan robot yang berbeda (perbedaan sudut pandang pengambilan citra) dan dengan kondisi iluminasi yang berbeda. Metode TL-AlexNet mampu mempertahankan nilai accuracy, precision, recall, dan F1 score di atas 87\% (Tabel 3). Dengan hasil pengujian tersebut, metode yang dikembangkan ini memiliki performa yang lebih baik dibandingkan terhadap metode konvensional dalam [17] dan dengan metode BoW dalam [10].
Tabel 2. Nilai accuracy, precision, recall, dan F1 score untuk masing-masing proses klasifikasi dataset York Univ (17 kategori) menggunakan metode TL dengan mengambil fitur $\mathrm{CNN}$ AlexNet pada layer 5 (Conv-5), 6 (FC-6), dan 7 (FC-7)

\begin{tabular}{ccccc}
\hline $\begin{array}{c}\text { CNN } \\
\text { Layer }\end{array}$ & Accuracy & Precision & Recall & $\begin{array}{c}\text { F1 } \\
\text { Score }\end{array}$ \\
\hline Conv-5 & 0,762 & 0,761 & 0,778 & 0,770 \\
FC-6 & 0,785 & 0,784 & 0,833 & 0,808 \\
FC-7 & 0,774 & 0,773 & 0,797 & 0,785 \\
\hline
\end{tabular}

Tabel 3. Nilai precision, recall, dan F1 score untuk masing-masing proses klasifikasi dataset York University (11 places) menggunakan metode TLAlexNet FC-6 dengan skema variasi iluminasi.

\begin{tabular}{cccc}
\hline Robot (Iluminasi) & Precision & Recall & $\begin{array}{c}\text { F1 } \\
\text { Score }\end{array}$ \\
\hline $\mathrm{Pi}-\mathrm{Pi}$ (Sama) & 0,984 & 0,985 & 0,984 \\
$\mathrm{VMe}-\mathrm{VMe}$ (Sama) & 0,985 & 0,986 & 0,986 \\
$\mathrm{Pi}-\mathrm{Pi}$ (Beda) & 0,966 & 0,966 & 0,966 \\
$\mathrm{VMe}-\mathrm{VMe}$ (Beda) & 0,927 & 0,934 & 0,930 \\
$\mathrm{Pi}-\mathrm{VMe}$ (Sama) & 0,902 & 0,913 & 0,908 \\
$\mathrm{VMe}-\mathrm{Pi}$ (Sama) & 0,957 & 0,959 & 0,958 \\
$\mathrm{Pi}-\mathrm{VMe}$ (Beda) & 0,826 & 0,857 & 0,841 \\
$\mathrm{VMe}-\mathrm{Pi}$ (Beda) & 0,878 & 0,894 & 0,886 \\
\hline
\end{tabular}

Pada tahap selanjutnya, pengujian pengenalan tempat dilakukan dengan menggunakan metode TLAlexNet FC-6 dengan video sequences secara offline, sebagaimana screenshoot hasil pengujian yang ditampilkan pada Gambar 9. Beberapa kategori citra memiliki kemiripan yang cukup tinggi, seperti beberapa sudut ruang WorkPlace yang sekilas mirip dengan 


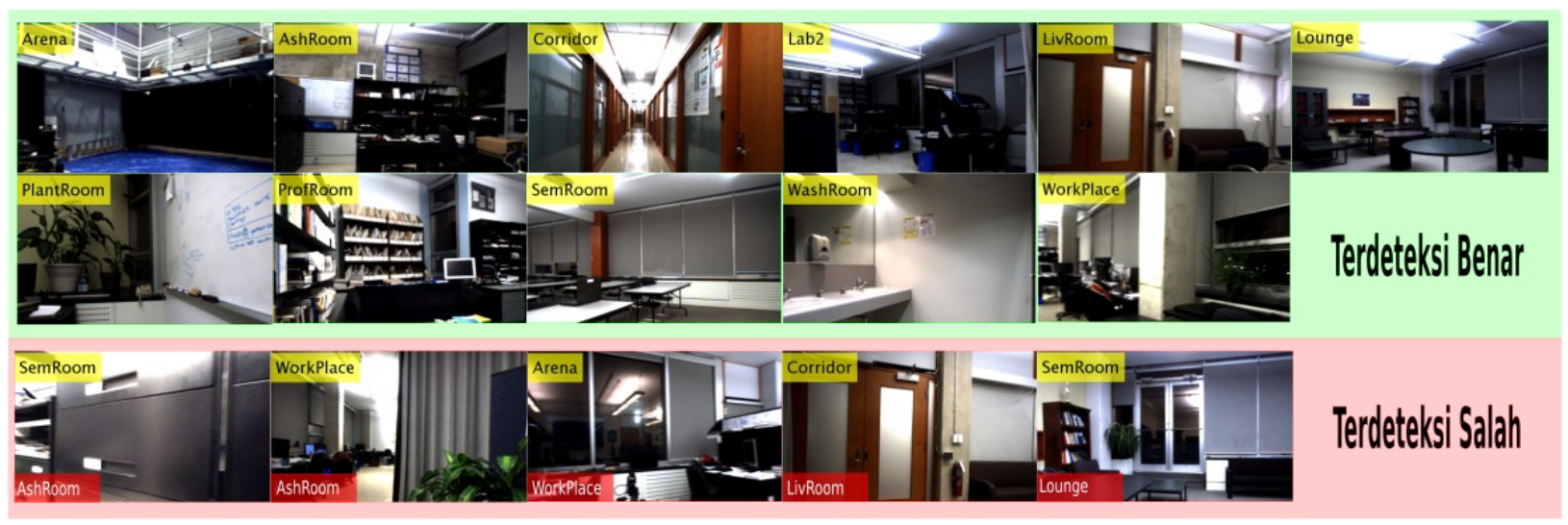

Gambar 9. Beberapa hasil proses pengenalan dan klasifikasi citra tempat indoor menggunakan dataset York Univ dengan kategori 11 jenis ruangan. Bagian atas merupakan screenshoot ketika algoritma berhasil mengenali tempat dengan benar, sedangkan bagian bawah saat algoritma salah dalam mengenali jenis ruangan.

SemRoom, atau sudut ruang berpintu pada LivRoom yang sekilas mirip Corridor. Namun, pada pengujian, secara umum kesalahan pengenalan tempat (misklasifikasi) cukup rendah, yakni rata-rata bernilai tidak lebih dari 7\%. Waktu komputasi untuk algoritma TLAlexNet FC-6 pada Matlab adalah antara 0,07-0,10 detik untuk memproses dan mengklasifikasikan citra lokasi indoor. Hasil ini cukup baik karena pada prakteknya algoritma bisa memproses video sequence dalam 10 FPS. Hal ini disebabkan arsitektur AlexNet yang cukup dalam, yaitu terdiri dari 8 layer.

\section{KESIMPULAN}

Metode Transfer Learning (TL) dari pre-trained CNN AlexNet pada FC-6, sebagai salah satu metode pengenalan tempat berbasiskan learned-features, cukup handal untuk pengenalan tempat pada robot-bergerak. Dalam hal akurasi dan kepresisian, metode ini lebih unggul dibandingkan dengan metode-metode konvensional lain berbasiskan handcrafted-features seperti BoW dan HOUP. Selain itu, metode ini memiliki keuntungan, antara lain lebih robust terhadap perubahan iluminasi cahaya, adaptable, dan dapat digunakan pada sudut pandang pengambilan citra yang berbeda. Namun, kekurangannya adalah dalam hal waktu komputasi. Metode ini belum cukup cepat untuk implementasi real time pada aplikasi robot-bergerak karena hanya mampu memproses video kurang lebih 10 FPS saja, padahal robot-bergerak bernavigasi lincah membutuhkan minimal 25-30 FPS. Ke depannya, untuk aplikasi realtime pada robot-bergerak, metode transfer learning dapat menggunakan arsitektur CNN lain yang memiliki jumlah layer lebih sedikit.

\section{UCAPAN TERIMA KASIH}

Penulis berterima kasih kepada Dr. Bogdan Kwolek dari AGH University of Science and Technology Krakow, Polandia, yang telah menjadi pembimbing sekaligus rekan diskusi dalam penelitian yang telah dilakukan. Penulis juga mengucapkan terima kasih kepada UNESCO dan AGH University of Science and Technology Krakow yang telah mendanai program penelitian pada UNESCO/Poland Co-Sponsored Fellowship Programme in Engineering 2017 yang dilakukan oleh penulis. Hasil penelitian ini merupakan salah satu bagian dari luaran program fellowship yang telah dilakukan.

\section{Daftar Pustaka}

[1] J. Fuentes-Pacheco, J. Ruiz-Ascencio, and J. M. Rendón-Mancha, "Visual Simultaneous Localization and Mapping: A Survey," Artificial Intelligence Review, vol. 43, no. 1, pp. 55-81, 2015.

[2] S. Lowry, N. Sünderhauf, P. Newman, J. J. Leonard, D. Cox, P. Corke, and M. J. Milford, "Visual Place Recognition: A Survey," IEEE Transactions on Robotics, vol. 32, no. 1, pp. 1-19, 2016.

[3] D. G. Lowe, "Object Recognition from Local Scale-invariant Features," in Proceedings of the Seventh IEEE International Conference on Computer Vision, Kerkyra, Greece, Sept. 1999, pp. 1150-1157.

[4] H. Bay, T. Tuytelaars, and L. Van Gool, "Surf: Speeded up Robust Features," in European Conference on Computer Vision, Berlin, Heidelberg, 2006, pp. 404-417.

[5] S. Leutenegger, M. Chli, and R. Y. Siegwart, "BRISK: Binary Robust Invariant Scalable Keypoints,“ in 2011 International Conference on Computer Vision, Barcelona, Spain, Nov. 2011, pp. 2548-2555.

[6] E. Rublee, V. Rabaud, K. Konolige, and G. Bradski, "ORB: An Efficient Alternative to SIFT or SURF," in 2011 International Conference on Computer Vision, Barcelona, Spain, Nov. 2011, pp. 2564-2571. 
[7] Z. Wang, F. Wu, and Z. Hu, "MSLD: A Robust Descriptor for Line Matching," Pattern Recognition, vol. 42, no. 5, pp. 941-953, 2009.

[8] C. G. Harris and M. Stephens, "A Combined Corner and Edge Detector.," in Proc. of Fourth Alvey Vision Conference, 1988, pp. 147-151.

[9] K. Chatfield, V. S. Lempitsky, A. Vedaldi, and A. Zisserman, "The Devil is in the Details: an Evaluation of Recent Feature Encoding Methods," in The 22nd British Machine Vision Conference, England, Sept. 2011, pp. 76.1-76.12.

[10] D. Gálvez-López and J. D. Tardos, "Bags of Binary Words for Fast Place Recognition in Image Sequences," IEEE Transactions on Robotics, vol. 28, no. 5, pp. 1188-1197, 2012.

[11] A. Torii, J. Sivic, T. Pajdla, and M. Okutomi, "Visual Place Recognition with Repetitive Structures," IEEE Transactions on Pattern Analysis and Machine Intelligence, vol. 37, no. 11, pp. 2346-2359, 2013.

[12] N. Sünderhauf, S. Shirazi, A. Jacobson, F. Dayoub, E. Pepperell, B. Upcroft, and M. Milford, "Place Recognition with Convnet Landmarks: Viewpointrobust, Condition-robust, Training-free," in Proceedings of Robotics: Science and Systems XI, Rome, Italy, July 2015.

[13] J. L. Schonberger, H. Hardmeier, T. Sattler, and M. Pollefeys, "Comparative Evaluation of Handcrafted and Learned Local Features," in Proceedings of the IEEE Conference on Computer Vision and Pattern Recognition, 2017.

[14] Q. Li, K. Li, X. You, S. Bu, and Z. Liu, "Place Recognition Based on Deep Feature and Adaptive Weighting of Similarity Matrix," Neurocomputing, vol. 199, pp. 114-127, 2016.

[15] L. Tai and M. Liu, "Deep-Learning in Mobile Robotics-From Perception to Control Systems: A
Survey on Why and Why Not," arXiv preprint arXiv:1612.07139 [cs], Dec. 2016.

[16] A. Krizhevsky, I. Sutskever and G. E. Hinton, "Imagenet Classification with Deep Convolutional Neural Networks," Communications of the ACM, vol. 60, no. 6, pp. 84-90, 2017.

[17] R. Sahdev and J. K. Tsotsos, "Indoor Place Recognition System for Localization of Mobile Robots," in 13th Conference on Computer and Robot Vision (CRV), Victoria, Canada, Jun. 2016, pp. 53-60.

[18] A. Quattoni and A. Torralba, "Recognizing Indoor Scenes," in 2009 IEEE Conference on Computer Vision and Pattern Recognition, Miami, USA, Jun. 2009, pp. 413-420.

[19] S. Krig, "Interest Point Detector and Feature Descriptor Survey,” in Computer Vision Metrics, Berkeley: Apress, 2014, pp. 187-246.

[20] A. Vedaldi and B. Fulkerson, "VLFeat: An Open and Portable Library of Computer Vision Algorithms," in Proc. of the 18th ACM International Conference on Multimedia, New York, USA, Oct. 2010, pp. 1469-1472.

[21] E. Fazl-Ersi and J. K. Tsotsos, "Histogram Of Oriented Uniform Patterns for Robust Place Recognition and Categorization," International Journal of Robotics Research, vol. 31, no. 2, pp. 468-483, 2012.

[22] O. Russakovsky et al., "Imagenet Large Scale Visual Recognition Challenge," International Journal of Computer Vision, vol. 115, no. 1, pp. 211-252, 2015.

[23] A. Vedaldi and K. Lenc, "Matconvnet: Convolutional Neural Networks for Matlab," in Proceedings of the 23rd ACM International Conference on Multimedia, Brisbane, Australia, Oct. 2015, pp. 689-692. 